\title{
A serdülókori pszichológiai jóllét multidimenzionális méróeszköze: Az EPOCH kérdőív magyar változatának (EPOCH-H) pszichometriai jellemzői
}

\author{
LÁNG ANDRÁS \\ Pécsi Tudományegyetem, Bölcsészettudományi Kar, Pszichológia Intézet, Pécs
}

(Beérkezett: 2018. május 15.; elfogadva: 2018. december 09.)

\begin{abstract}
Elméleti háttér: A pszichológiai jóllét a pozitív pszichológia egyik legfontosabb kutatási területe. Az elmúlt tíz évben tapasztalható fejlődést az elméleti modellek területén a mérőeszközök is követik. Ugyanakkor serdülőkorban még életkorilag nem várható el a pszichológiai jóllét összetevőinek teljes kibomlása. Erre a kihívásra ad választ az Engagement, Perseverance, Optimism, Connectedness, and Happiness Measure (EPOCH kérdóív). Cél: A vizsgálat célja az EPOCH kérdőív magyar adaptálása volt. Ennek során a magyarra fordított kérdőív strukturális megbízhatóságát, konkurrens, diszkrimináns és inkrementális validitását vizsgálatuk. Módszer: A vizsgálatban 758, 14-19 év közötti középiskolás vett részt. Szülői beleegyezés után egy kérdőívcsomagot töltöttek ki, amely az EPOCH kérdőív magyar fordításán kívül általános jóllétet, élettel való elégedettséget, szükségletkielégítettséget és általános kötődést mérő kérdőíveket tartalmazott. Eredmények: A konfirmatív (megerősítő) faktorelemzés alapján adataink jól illeszkedtek az eredeti modellel azonos ötfaktoros struktúrához. Az egyéb kérdőívekkel mutatott átlagosan közepes erősségú korrelációs együtthatók alapján elmondhatjuk, hogy az EPOCH-H kérdőív dimenziói megfelelő mértékben vágnak egybe és térnek el a jóllét hagyományosan mért mutatóitól. Az EPOCH-H kérdőív dimenziói a hagyományos jóllétmutatók hatását kontrollálva is szignifikáns kapcsolatot mutattak az általános kötődés és a pszichológiai szükségletkielégítettség dimenzióival. Következtetések: Az EPOCH-H kérdőív egy életkorilag adekvát, a nemzetközi fóáram elméleti modelljeihez jól illeszkedő mérőeszközt kínál azon kutatóknak, akik a serdülők jóllétét önkitöltős eszközzel és több dimenzió mentén kívánják vizsgálni.
\end{abstract}

Kulcsszavak: serdülőkor, jóllét, PERMA, EPOCH, pszichometria

\footnotetext{
* Levelezési cím: dr. Láng András, Pécsi Tudományegyetem, Bölcsészettudományi Kar, Pszichológia Intézet, 7624 Pécs, Ifjúság útja 6. E-mail: lang.andras@pte.hu
} 


\section{Bevezetés}

A pozitív pszichológia - mind nemzetközileg, mind pedig hazánkban - jelentős térnyeréssel büszkélkedhet az akadémiai pszichológia és az alkalmazott pszichológia területén is (Oláh \& Kapitány-Fövény, 2012). A pozitív szemlélet térnyerésének indulását a II. világháború utánra datálhatjuk, amikor az Egészségügyi Világszervezet (WHO, 1948, 1. o.) az egészséget az alábbiak szerint definiálta: „a teljes testi, szellemi és szociális jóllét állapota, nem pusztán a betegség vagy fogyatékosság hiánya". A pozitív pszichológia ennek megfelelően a pszichológiai jóllétet többnek tekinti, mint pusztán a mentális betegségek hiányát. Ennek a pszichológiai jóllétnek számos megfogalmazása közül napjainkban talán Seligmané (2011) a legelterjedtebb. A boldog életet virágzáshoz (flourishing) hasonlítja, amit talán magyarul a hétköznapokban szárnyalásként ${ }^{1}$ hivatkozott állapot ír le legjobban.

Kern, Benson, Steinberg és Steinberg (2016) a szárnyalásra olyan pozitív múködésként tekint, amely számos biopszichoszociális területet felölel. Ez az elképzelés jól illeszkedik Seligman (2011; 2018) PERMA-modelljéhez. A betúszó a felnőttkori szárnyalás öt aspektusának angol megnevezéséből ered: pozitív érzelmek (positive emotions), elmélyülés (engagement), kapcsolatok (relationships), értelemteliség (meaning) és teljesítmény (accomplishment). Kern és munkatársai (2016) azonban úgy gondolják, hogy a szárnyaláshoz szükséges területek serdülőkorban még bontakozóban vannak, megalapozásuk történik. Így egy olyan modellt dolgoztak ki, ahol az egyes területek nem a szárnyalás összetevőinek, hanem előfeltételeinek - életkori analógiás megfelelőinek - tekinthetők. Tehát az EPOCH-modellben megjelenő dimenziók a felnőttként majd szárnyalni képes kamaszt írják le, figyelembe véve a serdülőkor életkori sajátosságait. Az EPOCH-modellben a pozitív érzelmeknek a boldogság (happiness), az értelemteliségnek az optimizmus (optimism), a teljesítménynek a kitartás (perseveration) feleltethetó meg. Az elmélyülés azonos névvel (engagement), a kapcsolatok fontossága pedig kapcsolódásként (connectedness) jelenik meg az EPOCH-modellben.

Kern és munkatársai (2016) az öt dimenzió jelentésére az alábbi definíciókat adják. Az elmélyülés valamely tevékenységbe való bevonódásra, nagyfokú érdeklődésre utal. Kifejezett formája azonos a Csíkszentmihályi (2010) által megfogalmazott flow-élménnyel. A kitartás arra az állhatatosságra utal, amely lehetővé teszi, hogy a kihívások és akadályok ellenére is elkötelezettek maradhassunk hosszú távú terveink mellett. Az optimizmus a reményre, a jövő jó irányba alakulásába vetett hitre utal. Hozzátartozik, hogy a negatív

\footnotetext{
1 A virágzás a „flourishing” Oláh és Kapitány-Fövény (2012) által is használt szó szerinti fordítása. A késóbbiekben a magyar hétköznapi nyelvhasználathoz közelebb álló szárnyalás kifejezést használom a "flourishing" megjelölésére.
} 
tapasztalatokat átmenetiknek tekintjük, és pozitív hozzáállással fordulunk a jövő felé. A kapcsolódás annak megtapasztalását jelenti, hogy vannak olyan emberek körülöttünk, akikre számíthatunk, akik gondoskodnak rólunk, és akik számára mi is támaszt nyújtunk. A boldogság nem pillanatnyi érzést takar, hanem a megelégedettség és pozitív hangulat tartós érzését jelenti. Kern és munkatársai (2016) fontosnak tartják, hogy modelljüket - a jelentős átfedés ellenére - elkülönítsék a pozitív fiatalkori fejlődés (Positive Youth Developement - PYD; Lerner, Phelps, Forman, \& Bowers, 2009) modelljétól. Az EPOCH-modell inkább az egyéni erősségekre koncentrál a PYD-modell rendszerszintú megközelítésével szemben, és területáltalános - tehát például nem tesz különbséget aközött, hogy az elmélyülés élményét a tanulás vagy éppen a számítógépes játékok jelentik a serdülő számára - a PYDmodell kontextus-specifikusságával szemben.

A mérőeszköz pszichometriai jellemzőit tekintve az eredeti közlésben, négy különböző mintán Kern és munkatársai (2016) az öt korreláló faktoros modell illeszkedését megfelelőnek találták. Sőt, ez a modell az egyfaktoros és a fölérendelt faktoros megoldásnál is jobb illeszkedési mutatókkal rendelkezett. A szerzők ugyan az öt korreláló faktoros modellel a dimenziók különbözőségét hangsúlyozták, ugyanakkor a többi kapcsolathoz viszonyítva a boldogság dimenzió több más dimenzióval is erősebben korrelált. Kiemelkedően erôs együttjárást $(r=0,70)$ tapasztaltak a boldogság és az optimizmus között. A boldogság szakirodalmát ismerve ezen összefüggések nem meglepők. Lyubomirsky, King és Diener (2005) tanulmányukban számos, a pozitív affektushoz kapcsolódó konstruktumot sorolnak fel, amely az optimizmust, a társas beállítódást és a proszociális viselkedést (lásd EPOCH - kapcsolódás dimenzió) is tartalmazza.

A kérdőívvel - annak újdonsága miatt - longitudinális vizsgálatok még nincsenek, azonban az eszközt már adaptálták törökre (Demirci \& Ekşi, 2015), és felhasználták svéd (Haglund \& Massaro, 2016) és cseh (Šeboková, 2018) nyelven is, azonban e két utóbbi nyelven szisztematikus pszichometriai vizsgálódás nem történt. A török eredmények (Demirci \& Ekşii, 2015) szerint az öt egymással korreláló faktorból álló struktúra elfogadható illeszkedést mutatott $(\mathrm{CFI}=0,98$; $\mathrm{TLI}=0,96$; $\mathrm{RMSEA}=0,074$; $\mathrm{SRMR}=$ 0,052), az egyes dimenziók között egységesen közepestől erősig terjedő pozitív korrelációt kaptak ( $r=0,53$ és 0,78 között). Validálásként az Oxford Boldogság Skálát (Hills \& Argyle, 2002; idézi: Demirci \& Ekşi, 2015) használva mind az EPOCH összpontszámmal, mind pedig az egyes dimenziókkal gyengétől közepes erősségú pozitív korrelációt találtak.

A fentiekben ismertetettek alapján célkitúzésünk az volt, hogy az EPOCH kérdőívet (Kern és mtsai, 2016) magyarra fordítsuk és a magyar fordítás pszichometriai jellemzőit megvizsgáljuk. Ennek keretében a kérdőív strukturális megbízhatóságát, konkurrens, diszkriminatív és inkrementális validitását kívántuk vizsgálni. 


\section{Módszer}

\subsection{Minta és eljárás}

A vizsgálatban résztvevő fiatalok a „Serdülőkori jóllét, családtörténeti tudás és identitás", illetve "A serdülókori jóllét multidimenzionális mérése" címú, a Pszichológiai Kutatások Egyesült Etikai Bíráló Bizottsága által 2017/91 és 2017/103 számon jóváhagyott kutatásokban vettek részt. A vizsgálati minta toborzása az alábbiak szerint történt. Egyetemi hallgatók korábbi tanulmányaik helyszínéül szolgáló vagy más, számukra elérhető középiskolák vezetóit és tanárait keresték meg azzal a kéréssel, hogy diákjaik által személyesen kitöltött kérdőívek formájában biztosítsák az adatgyújtés lehetőségét. A kitöltés előtt legalább egy héttel a szülőket a vizsgálat céljáról és menetéről írásban tájékoztattuk. A vizsgálatban azok a diákok vettek részt, akiknek szülei vagy önmaguk nem jelezték sem előzetesen, sem menet közben a részvételtől való elállás szándékát. A kérdőívcsomag kitöltése anonim és önkéntes volt. Az egyetemi hallgatók az adatgyuujtést kurzusuk részleges teljesítéseként végezték. A résztvevők semmilyen ellenszolgáltatásban nem részesültek a kérdőívcsomag kitöltéséért. A két eltérő kutatás eltérő kérdőívcsomagjaiból fakadóan az EPOCH kérdőív magyar változatának faktorszerkezetét egy nagyobb mintán tudtuk vizsgálni, míg validitását a minta részmintáján.

A teljes minta nagyvárosi középiskolák 758 diákjából állt. A minta 57,8\%-a (438 fö) lány, 42,2 \%-a (320 fó) fiú volt. Életkoruk 14 és 19 év között mozgott. A teljes minta életkori átlaga 16,3 év volt (szórás: 1,10 év). A teljes minta validáláshoz felhasznált részmintája 417 főből állt. A részminta 55,2 \%-a (230fő) lány, 44,8 \%-a (187 fó) fiú volt. Életkoruk 14 és 18 év között mozgott. A részminta életkori átlaga 16,3 év volt (szórás: 1,20 év).

\subsection{Mérőeszközök}

A serdülőkori jóllét öt aspektusának mérésére a validálni kívánt EPOCH kérdóív (Kern és mtsai, 2016) magyar fordítását (EPOCH-H) használtuk. A fordítást szerző készítette, majd a visszafordított tételeket egy, az eredeti verzióra vak, angolul anyanyelvi szinten beszélő személy fordította vissza. Az eredeti és a visszafordított tételek összevetését szerző és visszafordító együttesen végezte. Közöttük jelentős, az értelmezést befolyásoló eltérést nem találtunk.

A kérdőív 20 állítást tartalmaz, amelyek a jóllét korábban már ismertetett öt aspektusát ragadják meg: elmélyülés, kitartás, optimizmus, kapcsolódás, boldogság. A kérdőívet a Függelék tartalmazza. A kitöltők 5-fokú, Likert- 
skálán értékelhették az állításokat aszerint, hogy mennyire tekintették jellemzőnek önmagukra ( 1 = szinte soha nem igaz; 5 = szinte mindig igaz). Ebben a pontozási rendszerben eltértünk az eredeti mérőeszköztől, ahol kilenc állítás esetében gyakoriságot kell megítélni. Tettük ezt ezért, mert úgy gondoltunk, hogy a magyarországi fiatalok kevésbé „tesztjártasak”, mint angolszász kortársaik, így az eredetiben sem konzekvensen alkalmazott változtatás a válaszadás mikéntjében inkább megzavarná, mintsem segítené őket. Az öt dimenzió mellett összpontszámot is számoltunk. Minden esetben átlagokkal dolgoztunk, így az egyes pontszámok egy és öt között mozoghattak.

Az általános jóllét mérésére a WHO Jól-lét Kérdőív 5 tételes változatát (WBI-5; Bech, Staehr-Johansen, \& Gudex, 1996; magyar változat: Susánszky, Konkolÿ Thege, Stauder, \& Kopp, 2006) vettük fel a kitöltókkel. A kérdőív az elmúlt két hétre vonatkozóan öt állítást tartalmaz (pl. „Vidámnak és jókedvúnek éreztem magam”), amelyek a személy általános közérzetére, pozitív életminőségére vonatkoznak. A válaszadók 4-fokú Likert-skálán jelezhették, mennyire tartották önmagukra jellemzőnek az egyes állításokat ( 0 = egyáltalán nem jellemző; 3 = teljesen jellemző). Az állításokra adott válaszok pontszámának összegéből számoltunk összpontszámot, így a kitöltők pontszáma nulla és 15 pont között mozoghatott.

Az élettel való elégedettséget az Élettel Való Elégedettség Skálával (SWLS; Diener, Emmons, Larsen, \& Griffin, 1985; magyar változat: Martos, Sallay, Désfalvi, Szabó, \& Ittzés, 2014) mértük. A kérdőív a pszichés jóllét kognitív aspektusát méri öt állítás segítségével (pl. „Kitúnőek az életkörülményeim"). Az állításokkal való egyetértésüket 7-fokú Likert-skálán jelezhették a válaszadók ( 1 = egyáltalán nem értek egyet; 7 = teljes mértékben egyetértek). Az állításokra adott válaszok pontértékeit összegeztük, így az összpontszám 5 és 35 között mozoghatott.

A szükségletek kielégitettségének mérésére az Alapvető Pszichológiai Szükségletek Kielégítettsége Skálát (BPNS; Deci \& Ryan, 2000; Gagné, 2003; magyar változat: Csókási \& Láng, 2018). A BPNS kérdőív 21 állítása három alapvető pszichológiai szükséglet kielégítettségének megélését méri. Az autonómia szükséglete arra utal, hogy cselekedeteinket és azok következményeit önindítottnak éljük meg. Az autonómia szükséglet kielégítettségét hét állítás méri (pl. „Úgy érzem, szabadon eldönthetem, hogyan élem az életemet"). A kompetencia szükséglete a feladatmegoldásban mutatkozó énhatékonyságra és képességre vonatkozik. A kompetenciaszükséglet kielégítettségét hat állítás méri ( $\mathrm{pl}$. „Az ismerőseim azt mondják, hogy jó vagyok abban, amit csinálok"). A kapcsolódási szükséglet a gondoskodó, támogató kapcsolatok iránti igényünket jelöli. A kapcsolódási szükséglet kielégültségét nyolc állítás méri (pl. „A körülöttem lévő emberek törődnek velem"). A kitöltők 7-fokú Likert-skálán ( 1 = egyáltalán nem igaz; 7 = telje- 
sen igaz) jelölték az állításokkal való egyetértésük mértékét. Az egyes mért változók pontszámát az állításokra adott válaszok pontszámainak összegéből számoltuk. Összpontszámot a BPNS kérdőív esetében nem számoltunk.

Az általános kötődési minőséget a Közvetlen Kapcsolatok Élményei - Kapcsolati Struktúrák (Fraley, Heffernan, Vicary, \& Brumbaugh, 2011; magyar változat: Jantek \& Vargha, 2016) kérdőív általános megfogalmazású változatával mértük. A kérdőív állításai úgy lettek kialakítva, hogy a kötődési elkerülés és szorongás mértékét különböző típusú kötődési kapcsolatokban lehessen mérni. Jelen vizsgálatban az általános kötődési reprezentációt mértük. Fraley és munkatársai (2011) javaslata alapján a kérdőív kilenc állításból álló változatát használtuk. A kilenc állításból hat a kötődési elkerülést, vagyis a jelentős másokról alkotott negatív reprezentációt, illetve az intimitás kerülését méri (pl. „Nem szívesen nyílok meg a hozzám közelálló emberekhez"), míg három a kötődési szorongásra, vagyis a szelfről alkotott negatív reprezentációra, illetve a szeparációtól való félelemre vonatkozik (pl. „Félek, hogy a hozzám közelálló emberek esetleg elfordulnak tőlem”). Az állításokkal való egyetértésüket 7-fokú Likert-skálán ( 1 = nagyon nem értek egyet; 7 = nagyon egyetértek) jelezhették a kitöltők. Mindkét kötődési dimenzió (ti. kötődési elkerülés és szorongás) esetében az állításokra adott válaszok pontértékének átlagával számoltunk.

\subsection{Statisztikai elemzések}

Az EPOCH-H kérdőív elméletileg meghatározott lehetséges szerkezeti felépítéseit megerósítő (konfirmatív) faktoranalízis segítségével vizsgáltuk. Az illeszkedés megfelelőségének elbírálásakor az alábbi vágóértékekre támaszkodtunk (Hu \& Bentler, 1998). Elfogadható illeszkedést mutat: NFI > 0,90; TLI $>0,90 ;$ CFI $>0,90$; RMSEA $<0,08$ és SRMR $<0,08$. Jó illeszkedést mutat: NFI > 0,95; TLI > 0,95; CFI > 0,95; RMSEA < 0,05; SRMR < 0,05.

Minden kérdőívskála esetében átlagot és szórást, illetve belső megbízhatósági mutatókat (Cronbach-a) számoltunk. Az EPOCH-H kérdőív dimenzióinak összefüggését egymással, a többi mért változóval és az életkorral Pearson-féle korrelációs elemzéssel teszteltük. A fiúk és lányok EPOCH-H kérdőív dimenzióin elért pontszámait egyszempontú varianciaanalízis segítségével hasonlítottuk össze. Ennek oka az volt, hogy az esetleges szóráskülönbségekből adódó korrekció szükségességét elkerüljük. A csoportok közötti különbségek nagyságának meghatározására Cohen-d értékeket számítottunk.

Az EPOCH-H kérdőív dimenzióinak kapcsolatát az alapvető pszichológiai szükségletek kielégítettségével és a kötődés két dimenziójával többszörös hierarchikus lineáris regresszióelemzés segítségével is megvizsgáltuk. 
Az első modellben a függő változókat az általános jóllét és az élettel való elégedettség hagyományos mérőeszközeiból származó pontszámokra regresszáltuk, majd a második modellben a független változókat kiegészítettük az EPOCH-H dimenzióinak pontértékeivel. Bár a regresszióelemzések esetében használt szakkifejezések (pl. függő változó, prediktor változók, magyarázott variancia) ok-okozati kapcsolatra utalhatnak, elemzésünk célja tulajdonképpen egyfajta kiterjesztett parciális korreláció futtatása volt (Cohen, Cohen, West, \& Aiken, 2013), ahol egy-egy függő változó és az öt EPOCH-H dimenzió együttes kapcsolatát tudtuk vizsgálni az általános jóllét és az élettel való elégedettség hagyományos méróeszközei pontszámának kontrollálása mellett.

\section{Eredmények}

Az EPOCH kérdơív magyar változatának faktorstruktúráját úgy alakítottuk ki, hogy az elméletileg meghatározott öt faktort tartalmilag megtartottuk, és az öt faktoron alkalmazható, elrendezésükben különböző lehetőségek (Credé \& Harms, 2015) illeszkedését konfirmatív (megerősítő) faktoranalízis segítségével ellenőriztük. Mivel az eredeti angol nyelvú kérdőív (Kern és mtsai, 2016) optimizmus- és boldogságdimenziója erősen korrelált ( $r=$ $0,70)$, ezért egy négy faktort tartalmazó modell is bekerült a tesztelendő lehetőségek közé. Az alternatív modellek illeszkedési mutatóit az 1. táblázat tartalmazza. A legjobb illeszkedést az öt egymással korreláló faktort tartalmazó megoldás mutatta. Hét hibakovariancia (1. és 16., 14. és 16., 2. és $17 .$, 13. és 18., 6. és 8., 7. és 12., 11. és 12. tétel hibái közé) beillesztésével az illeszkedés még tovább volt javítható. Így az illeszkedési mutatók az alábbi értékekre változtak: $\chi^{2}(153)=427,321 ; \mathrm{p}<0,001 ; \chi^{2} / \mathrm{df}=2,793 ; \mathrm{NFI}=0,916$; TLI $=0,930 ; \mathrm{CFI}=0,944 ; \mathrm{RMSEA}=0,049(90 \% \mathrm{CI}=0,043-0,054)$; $\mathrm{SRMR}=0,042$. A korábban bemutatott vágóértékek alapján a modell elfogadható (NFI, TLI és CFI alapján) vagy akár jó (RMSEA és SRMR) illeszkedésúnek is tekinthetó. Az öt egymással korreláló faktorból álló modellhez tartozó faktorsúlyokat a 2. táblázat mutatja be. A fentiek alapján elmondhatjuk, hogy a magyar változattal, magyar serdülők mintáján is sikerült a Kern és munkatársai (2016) által feltárt ötfaktoros struktúrát reprodukálnunk. A teljes mintán az egyes jóllét dimenziók belső megbízhatósága is megfelelóen alakult (3. táblázat). Az EPOCH-H dimenziói az EPOCH-H összpontszámmal közepestől erősig terjedő erősségú szignifikáns pozitív korrelációt mutattak, míg az EPOCH-H dimenziók közötti korrelációk szintén szignifikánsak és pozitívak voltak, gyengétôl közepesig terjedő erősséggel (4. táblázat). A korrelációk között az angol nyelvú változathoz (Kern és mtsai, 2016) hasonlóan kiemelkedő erősségú korrelációt találtunk az optimizmus és a boldogság dimenziók között. 
1. táblázat. Az EPOCH-H kérdőív lehetséges faktorszerkezeteinek illeszkedési mutatói; a megerősítő faktorelemzés eredményei

\begin{tabular}{|c|c|c|c|c|c|c|}
\hline $\begin{array}{c}\text { Modell } \\
\text { (hibakovarianciák nélkül) }\end{array}$ & $X^{2} / \mathrm{df}$ & NFI & TLI & CFI & $\begin{array}{l}\text { RMSEA } \\
(90 \% \mathrm{CI})\end{array}$ & SRMR \\
\hline Öt független faktoros modell & 8,035 & 0,730 & 0,726 & 0,755 & $\begin{array}{c}0,096 \\
(0,092- \\
0,101)\end{array}$ & 0,1870 \\
\hline Egyfaktoros modell & 10,935 & 0,633 & 0,613 & 0,654 & $\begin{array}{c}0,115 \\
(0,110- \\
0,119)\end{array}$ & 0,1019 \\
\hline $\begin{array}{l}\text { Öt faktor egy fölérendelt } \\
\text { faktorral modell }\end{array}$ & 3,783 & 0,877 & 0,892 & 0,906 & $\begin{array}{c}0,061 \\
(0,056- \\
0,066)\end{array}$ & 0,0607 \\
\hline Öt korreláló faktoros modell & 3,336 & 0,895 & 0,909 & 0,923 & $\begin{array}{c}0,056 \\
(0,050- \\
0,061)\end{array}$ & 0,0466 \\
\hline Bifaktoros modell & 3,660 & 0,892 & 0,896 & 0,918 & $\begin{array}{c}0,059 \\
(0,054- \\
0,065)\end{array}$ & 0,0570 \\
\hline $\begin{array}{l}\text { Négy korreláló faktoros } \\
\text { modell összevont Boldogság } \\
\text { és Optimizmus faktorokkal }\end{array}$ & 4,554 & 0,853 & 0,862 & 0,880 & $\begin{array}{c}0,069 \\
(0,064- \\
0,074)\end{array}$ & 0,0543 \\
\hline
\end{tabular}

Megjegyzés: a legjobban illeszkedő modellt félkövér betúvel emeltük ki.

Az EPOCH-H dimenzióinak összefüggése a demográfiai változókkal (nem és kor) az alábbiak szerint alakult. Egyszempontos varianciaanalízis felhasználásával összehasonlítottuk az EPOCH-H dimenzióinak pontszámait és összpontszámát fiúk és lányok között. Az eredményeket a 3. táblázatban mutatjuk be. Ezen eredmények alapján az összpontszámban nem mutatkozott különbség a fiúk és a lányok között, tehát általánosságban vett jóllétük azonos szinten volt. A dimenziók bontásában azonban minden dimenzió esetén szignifikáns különbséget találtunk a nemek között. Míg a fiúk szignifikánsan több pozitív érzelmet éltek meg (boldogság) és pozitívabb elvárásokkal voltak a jövőjük iránt (optimizmus), mint a lányok, addig a lányok a tevékenységekbe való bevonódást (elmélyülés), az azokba való hosszútávú befektetést (kitartást) és kapcsolataik támogató jellegét (kapcsolódás) tekintették magukra jellemzőbbnek a fiúknál. Ugyanakkor fontos megjegyezni, hogy a nemi csoportok közötti különbség a Cohen-d értékek alapján elhanyagolható mértékú volt. Az EPOCH-H dimenziók életkorral való összefüggését Pearson-féle korrelációval teszteltük, azonban sem az összpontszám, sem a dimenziók tekintetében nem kaptunk szignifikáns összefüggést (4. táblázat). 


\begin{tabular}{|c|c|c|c|c|c|c|c|c|c|c|c|c|c|}
\hline & 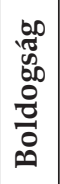 & & & & & & & & & & & & \\
\hline & 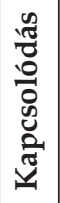 & & & & & & & & & & & & \\
\hline 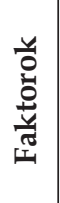 & 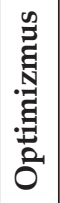 & & & & & & & & & $\stackrel{\Omega}{\stackrel{\Omega}{0}}$ & 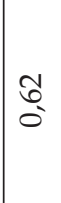 & $\begin{array}{l}\infty \\
\infty \\
0 \\
0\end{array}$ & ட̊ \\
\hline & 忢 & & & & & 로 & $\begin{array}{l}\text { ถે } \\
\text { ڤે }\end{array}$ & $\begin{array}{l}0 \\
\text { مn } \\
0\end{array}$ & రి & & & & \\
\hline & 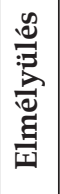 & $\begin{array}{l}1 \\
\text { ถุ } \\
\text { o }\end{array}$ & 会 & రై & $\begin{array}{l}\text { రె } \\
\text { రి }\end{array}$ & & & & & & & & \\
\hline 离 & & 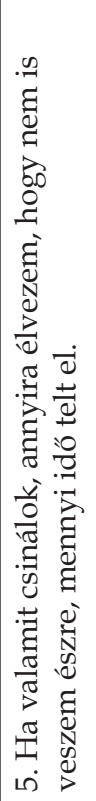 & 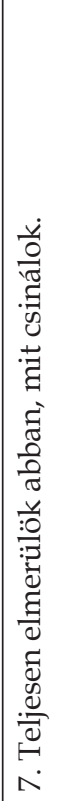 & 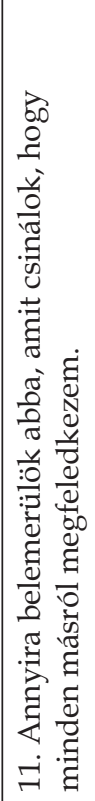 & 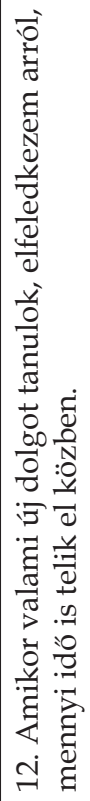 & 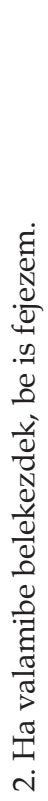 & 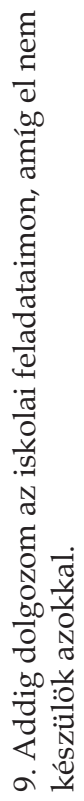 & 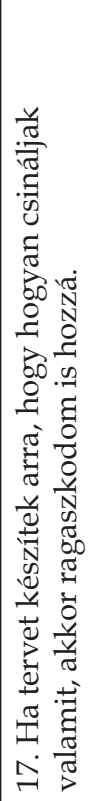 & 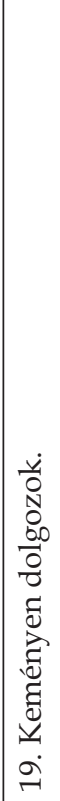 & 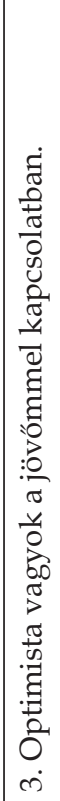 & 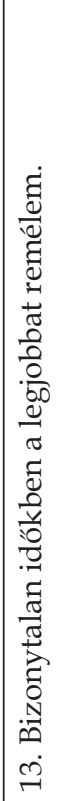 & 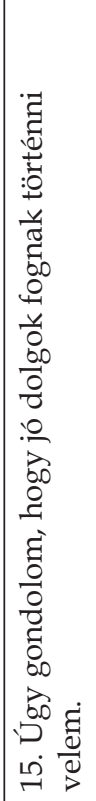 & 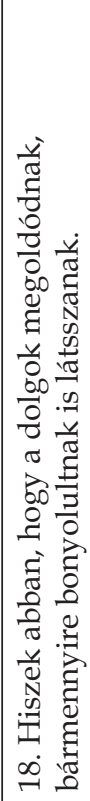 \\
\hline
\end{tabular}




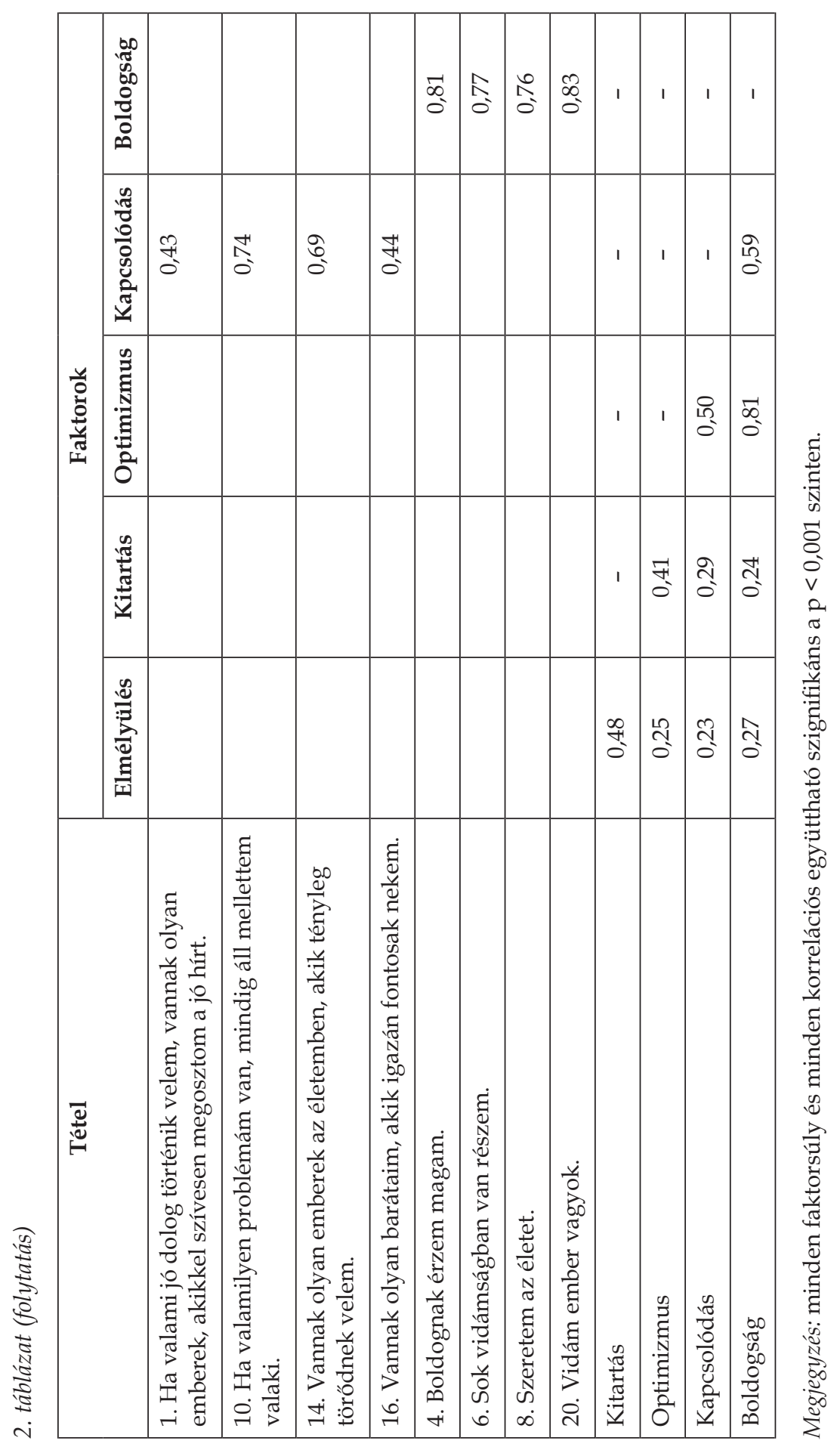




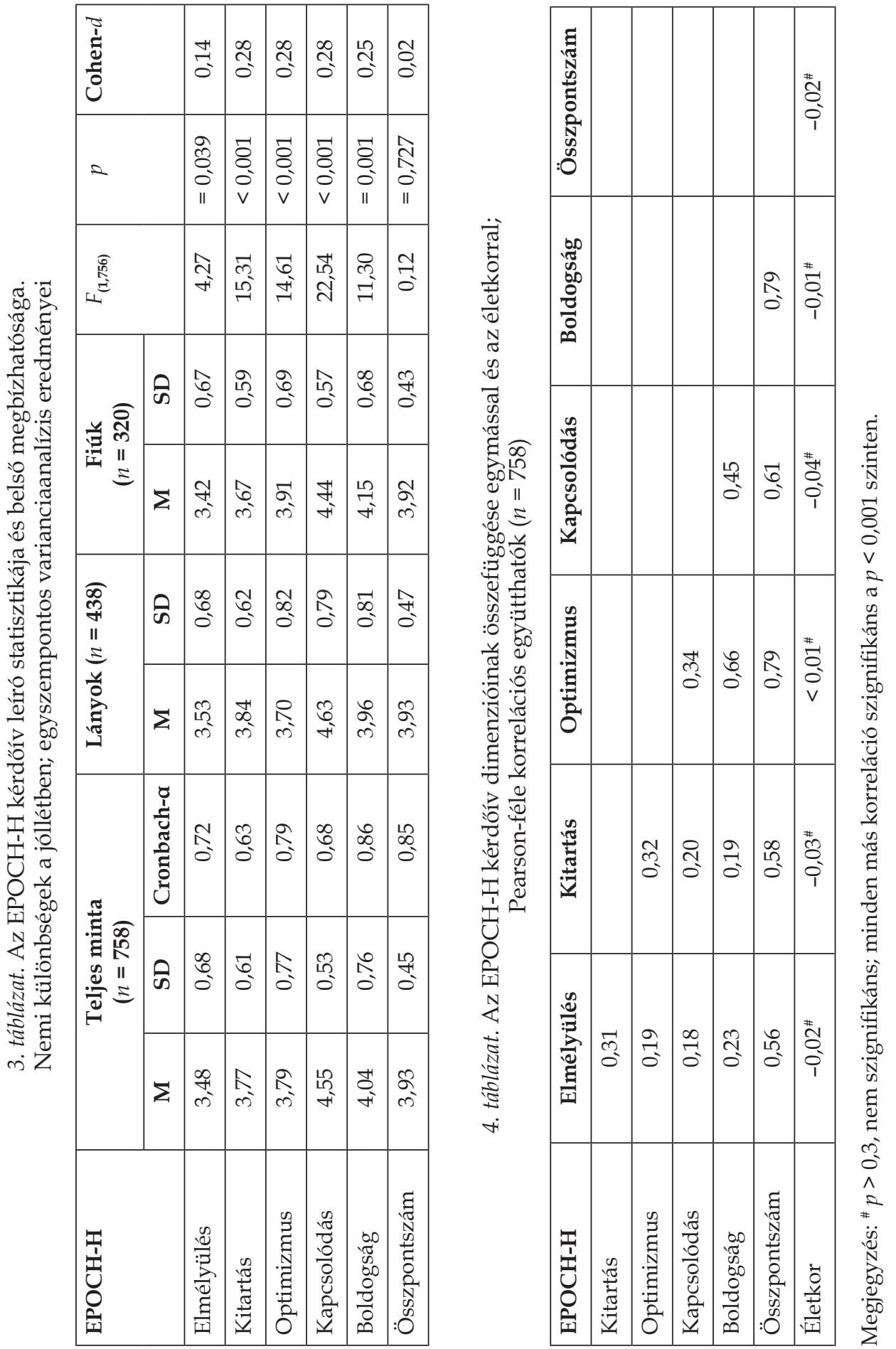




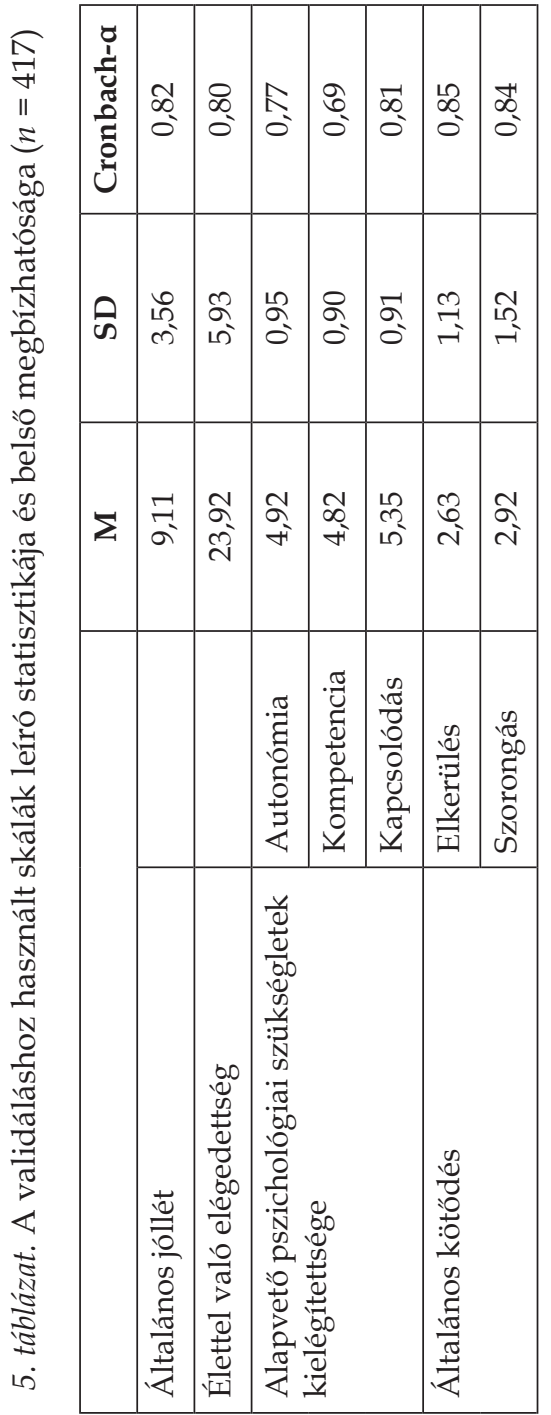

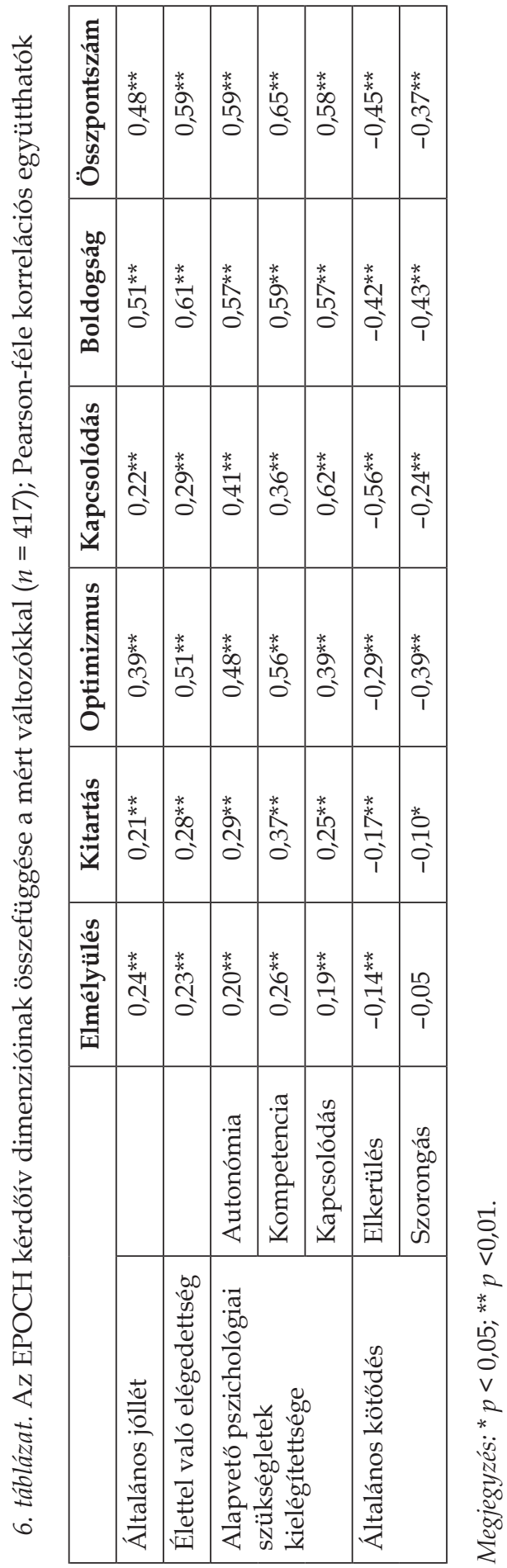


A validálásban használt kérdőívek skáláinak átlagait, szórásait és belső megbízhatósági értékeit az 5. táblázat tartalmazza. Ez alapján elmondható, hogy a használt kérdőívek belső megbízhatóság megfelelő volt. A validáláshoz első lépésben Pearson-féle korrelációs elemzéssel vizsgáltuk az EPOCH-H és a validáló skálák összefüggéseit (6. táblázat). Az EPOCH-H dimenziói és összpontszáma az elvárt irányú kapcsolatokat mutatták az általános jólléttel, az élettel való elégedettséggel, az autonómia, a kompetencia és a kapcsolódási szükséglet kielégítettségével. A korrelációk minden esetben szignifikánsak és pozitívak voltak, erősségük a nagyon gyengétől a közepes erősségúig változott. Az EPOCH-H öt dimenziója és összpontszáma szignifikáns, negatív korrelációt mutattak az általános kötódési elkerüléssel. A korrelációk erőssége a nagyon gyengétől a közepesig terjedt. Az általános kötődési szorongás az elmélyüléssel és kitartással nem, vagy csak nagyon gyenge szignifikáns kapcsolatot mutatott. Az EPOCH-H három fennmaradó dimenziójával és összpontszámával az általános kötődési szorongás gyengétől közepesig terjedő erősségú negatív szignifikáns korrelációt mutatott.

Az EPOCH-H dimenziók a pszichológiai jóllétet hagyományos módon mérő skálákon felüli kapcsolatát a pszichológiai szükségletek kielégítettségével és az általános kötődéssel hierarchikus többszörös lineáris regresszióelemzések segítségével vizsgáltuk. Mivel az EPOCH-H dimenziói között szignifikáns korreláció mutatkozott (4. táblázat), ezért először a multikollinearitás mértékét teszteltük. A VIF-értékek minden esetben 2,5 alattiak voltak, ami arra utalt, hogy a multikollinearitásból fakadó torzító hatás elhanyagolható (Mansfield \& Helms, 1982).

A regresszióelemzések eredményeit a 7. táblázatban foglaltuk össze. Eredményeink szerint az EPOCH-H dimenziói minden függő változó esetében szignifikáns növekedést idéztek elő a magyarázott variancia mértékében a hagyományos jóllét és élettel való elégedettség skálák felett. Az EPOCH-H dimenzióinak modellbe kerülése a legnagyobb változást a kapcsolódás szükségletének kielégítettsége (30\%) és az általános kötődési elkerülés (26\%) esetében eredményezte, és mindkét esetben az EPOCH-H kapcsolódás dimenziója bizonyult kimagaslóan a legerósebb prediktor változónak. Az EPOCH-H boldogság dimenziója minden függő változó esetében szignifikáns prediktornak bizonyult. A modellekben az EPOCH-H elmélyülés dimenziója játszotta a legelhanyagolhatóbb szerepet, amely csupán a kötődési szorongás esetében volt szignifikáns prediktor, méghozzá pozitív irányban. Tehát a többi változóra kontrollálva elmondhatjuk, hogy az aktivitásokba való intenzívebb bevonódás magasabb kötődési szorongással, erősebb szeparációs félelmekkel jár együtt. A fenti általános mintázattól a kompetenciaszükséglet kielégítettségére vonatkozó modell tért el jelentősen. A kompetenciaszükséglet kielégítettségével az EPOCH-H kitartás és optimizmus di- 


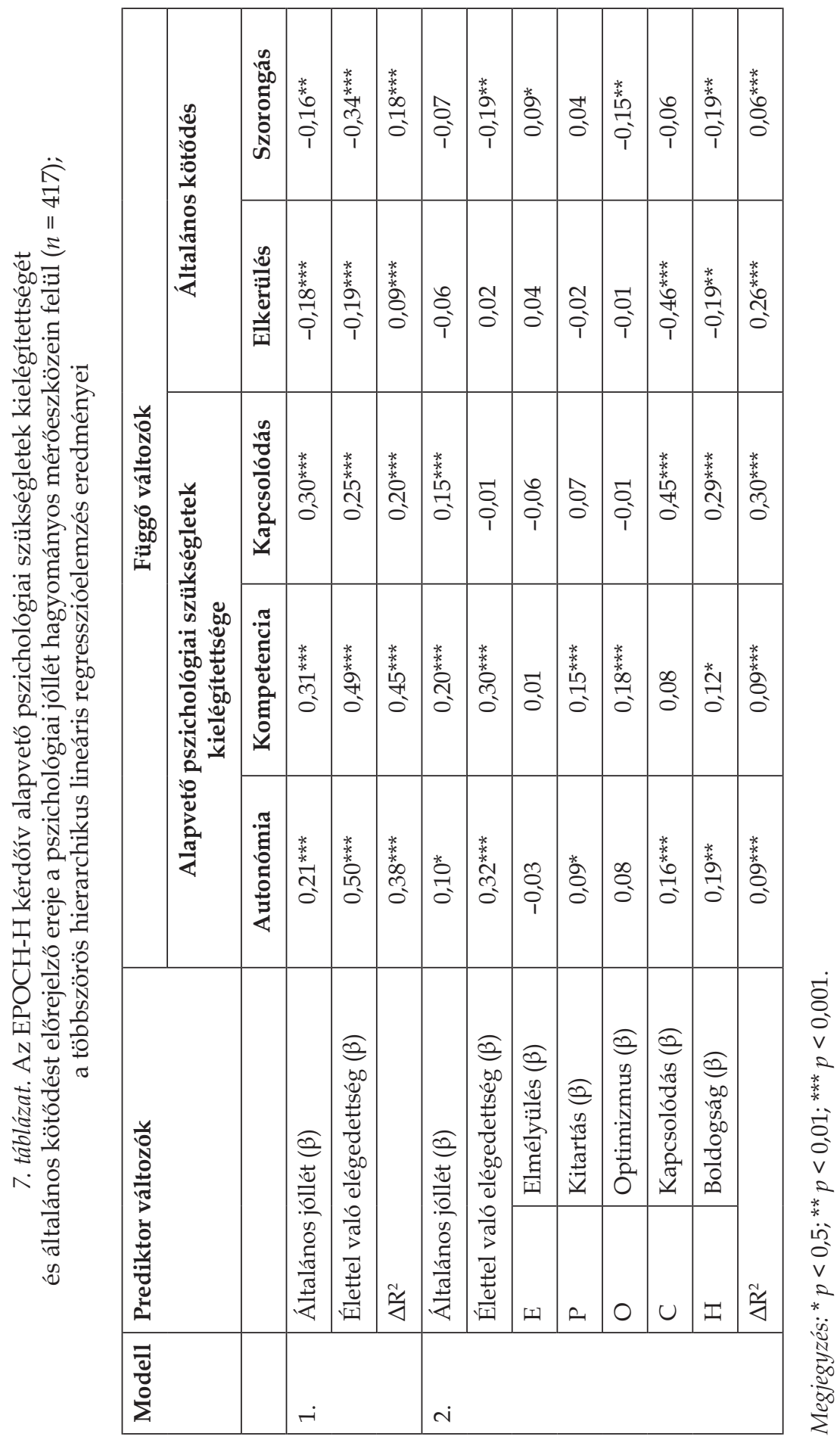


menziói mutatták a legerősebb kapcsolatot. Tehát azok a serdülők, akik tevékenységeik iránt elkötelezettebbek és jövőjükre pozitívabb várakozással tekintők voltak, magasabb szintú kompetenciaélményt éltek meg társaiknál.

\section{Megbeszélés}

Az EPOCH-H kérdőív struktúrája - öt egymással korreláló faktor - megfelelő illeszkedést mutatott az adatokhoz, és a kérdőív egyes dimenzióinak belső megbízhatósága is elfogadhatónak bizonyult vizsgálatunkban. A fent bemutatott értékek mind a török adaptálás eredményeivel (Demirci \& Ekşi, 2015), mind pedig Kern és munkatársai (2016) által az angol nyelvú eredeti kérdőívvel különböző vizsgálatokban nyert illeszkedési és megbízhatósági mutatókkal összhangban állnak. Ugyanígy összevethetók a kérdőív dimenziói, illetve a dimenziók és az összpontszám között talált korrelációk erősségei.

Bár az EPOCH-H kérdőív öt dimenziójában lányok és fiúk között mutatkozó szignifikáns különbségek nagysága elhanyagolható mértékú volt, irányaikban mégis összhangban állnak a korábbi kutatások által feltárt öszszefüggésekkel. A fiúk magasabbra értékelt boldogsága és optimizmusa az affektusok és a világlátás szintjén megfeleltethető a depresszió előfordulásában mutatkozó nemi különbségeknek. A kutatási eredmények (pl. Avison \& McAlpine, 1992; Cyranowski, Frank, Young, \& Shear, 2000) ugyanis azt mutatják, hogy a serdülőkortól kezdődően a lányok körében magasabb arányban fordul elő depresszió, amely éppen a boldogság és optimizmus inverzeiként negatív affektivitással és reménytelenséggel jár együtt (pl. Perczel-Forintos, Sallai, \& Rózsa, 2001).

Cross, Copping és Campbell (2011) az impulzivitásban megmutatkozó nemi különbségek metaanalitikus vizsgálatában kimutatták, hogy a fiúkraférfiakra jellemző magasabb impulzivitás, elsősorban a motivációs területen jelentkezik. Ennek tükrében nem meglepó azon eredményünk, miszerint a lányok intenzívebb feladatokba való bevonódásról és magasabb kitartásról számoltak be. Ugyanígy a magasabb kapcsolati jóllét is összhangban áll a korábbi kutatási eredményekkel, amelyek magasabb társas támogatottságot (Cheng \& Chan, 2004; Rueger, Malecki, \& Demaray, 2008) és kapcsolati elégedettséget (Calmes \& Roberts, 2008; Thomas \& Daubman, 2001) mutattak ki serdülő lányoknál a fiúkkal történt összehasonlításban.

Az EPOCH-H dimenzióinak elvárt irányú és átlagosan közepes erősségú korrelációival az általános jóllét, az élettel való elégedettség, az alapvető pszichológiai szükségletek kielégítettsége és az általános kötődési dimenziók tekintetében az EPOCH-H dimenziók konkurrens és diszkrimináns validitása is bizonyítást nyert. Az EPOCH-H elmélyülés, kitartás és optimizmus dimenziói a kompetenciaszükséglet kielégültségével - a feladatmegoldásra vonatkozó énhatékonysággal és képességgel - mutatták a leg- 
erősebb kapcsolatot. Ez nem meglepő, hiszen az elmélyülés flow-élményhez hasonló jellege (Csíkszentmihályi, 2010; Oláh, 1999), illetve a kitartás a célok és feladatok melletti elkötelezettség képességeként (Kern és mtsai, 2016) közvetlenül is kapcsolódik a feladathelyzetekhez, kihívásokhoz. Az optimizmus, mint a pozitív jövő elképzelésének képessége pedig úgy kapcsolódhat a kompetenciaszükséglet kielégültségéhez, hogy a sikeres, hatékony serdülők a kontroll és ágencia érzésein keresztül a jövő alakíthatóságát, pozitív irányban történő megváltoztathatóságát élik meg (Snyder, 2000).

A kapcsolódás dimenzió a kapcsolódás szükséglet kielégültségével és a kötődési elkerüléssel korrelált legerősebben. Így ebben a dimenzióban a jóllétnek egy alapvetóen a társas támogatottsággal, a másokról alkotott pozitív reprezentációval összekapcsolódó aspektusáról beszélhetünk (Moore és mtsai, 2018; Raja, McGee, \& Stanton, 1992). A boldogság dimenzió minden célváltozóval (általános jóllét, élettel való elégedettség, pszichológiai szükségletek kielégítettsége, általános kötődési dimenziók) közel azonos erősségben korrelált. Tehát a megélt jóllétnek a boldogság egy területáltalános érzelmi (Fredrickson, 2001) vagy értékelési/értelmezési aspektusát jeleníti meg (Diener \& Lucas, 2000). Ez összhangban áll a boldogságorientáció három aspektusa közül kettővel - az élvezetkereső és az értelemkereső boldogsággal (Szondy \& Martos, 2014).

Az EPOCH-H dimenziók inkrementális validitását tekintve elmondhatjuk, hogy mind az alapvető pszichológiai szükségletek, mind pedig az általános kötődési elkerülés és szorongás esetében az EPOCH-H dimenzióinak összessége szignifikáns kapcsolatban állt a célváltozókkal. Mindez az általános jóllét (WBI-5; Bech és mtsai, 1996; Susánszky és mtsai, 2006) és az élettel való elégedettség (SWLS; Diener és mtsai, 1985; Martos és mtsai, 2014) hagyományos mérőeszközeivel nyert értékeken felül valósult meg. Ehhez átlagosan legerősebben az EPOCH-H kapcsolódás dimenziója járult hozzá. Ez az eredmény nem meglepó, hiszen a kapcsolatok fontossága mind az EPOCH kérdőívben (Kern és mtsai, 2016), mind pedig az alapvetó pszichológiai szükségletek kielégítettségében (Deci \& Ryan, 2000) fontos szerepet játszik. Ugyanakkor meg kell jegyeznünk, hogy az EPOCH-H kapcsolódás dimenziója az Alapvetó Pszichológiai Szükségletek Kielégítettsége Skála (BPNS) azonos nevú dimenziójához képest tágabb jelentésú, mivel nemcsak a kapcsolati szükséglet kielégítettségére, hanem a kapcsolatok kölcsönösségére is hangsúlyt fektet. A fentiek mellett a serdülőkor fejlődési sajátosságait (Roisman, Masten, Coatsworth, \& Tellegen, 2004) és a jóllét biopszichoszociális megközelítésének társas aspektusát is szem előtt tartva (pl. Fava \& Sonino, 2008; Oláh \& Kapitány-Fövény, 2012) jogosnak tarthatjuk a mérőeszköz kapcsolati hangsúlyát, amely valóban újdonságként jelenik meg a WBI-5 vagy az SWLS kérdőívekhez képest. 
Vizsgálatunk korlátjaként említhető, hogy kizárólag önbeszámolókon alapult, így az EPOCH-H ökológiai validitásának tesztelése nem valósulhatott meg. Kifinomultabb módszerekkel (pl. narratív pszichológiai tartalomelemzéssel [László, 2011]) későbbi vizsgálatok ezt a hiányt pótolhatják. Eredményeink ugyanakkor azt mutatják, hogy a hagyományos mérőeszközök (WBI-5 és SWLS) kiegészítéseként is jól használható, rövid, multidimenzionális jóllétet mérő eszköz vált elérhetôvé azon kutatók számára, akik magyar anyanyelvú serdülők körében kívánják vizsgálni a jelenséget. 


\section{Irodalom}

Avison, W.R., \& McAlpine, D.D. (1992). Gender differences in symptoms of depression among adolescents. Journal of Health and Social Behavior, 33, 77-96.

Bech, P., Gudex, C., \& Johansen, K.S. (1996). The WHO (Ten) well-being index: validation in diabetes. Psychotherapy and psychosomatics, 65(4), 183-190.

Calmes, C. A., \& Roberts, J. E. (2008). Rumination in interpersonal relationships: Does corumination explain gender differences in emotional distress and relationship satisfaction among college students? Cognitive Therapy and Research, 32(4), 577-590.

Cheng, S.T., \& Chan, A.C. (2004). The multidimensional scale of perceived social support: dimensionality and age and gender differences in adolescents. Personality and Individual Differences, 37(7), 1359-1369.

Cohen, J., Cohen, P., West, S.G., \& Aiken, L.S. (2003). Applied multiple regression/correlation analysis for the behavioral sciences ( $3^{\text {rd }}$ ed.). Mahwah, NJ: Erlbaum

Credé, M., \& Harms, P.D. (2015). 25 years of higher-order confirmatory factor analysis in the organizational sciences: A critical review and development of reporting recommendations. Journal of Organizational Behavior, 36, 845-872.

Cross, C.P., Copping, L.T., \& Campbell, A. (2011). Sex differences in impulsivity: a metaanalysis. Psychological Bulletin, 137(1), 97-130.

Cyranowski, J.M., Frank, E., Young, E., \& Shear, M.K. (2000). Adolescent onset of the gender difference in lifetime rates of major depression: a theoretical model. Archives of General Psychiatry, 57(1), 21-27.

Csíkszentmihályi, M. (2010). Flow: az áramlat: a tökéletes élmény pszichológiája. Budapest: Akadémiai Kiadó

Csókási, K., \& Láng, A. (2018). Az Alapvető Pszichológiai Szükségletek Kielégítettsége Skála magyar változatával szerzett tapasztalatok. Közöletlen nyersadat.

Deci, E.L., \& Ryan, R.M. (2000). The "what" and "why" of goal pursuits: Human needs and the self-determination of behavior. Psychological Inquiry, 11(4), 227-268.

Demirci, İ., \& Ekşi, F. (2015). Ergenler için beş boyutlu iyi oluş modeli: EPOCH ölçeği'nin Türkçe formunun geçerliği ve güvenirliği. Gençlik Araştırmaları Dergisi, 3(3), 9-30.

Diener, E.D., Emmons, R.A., Larsen, R.J., \& Griffin, S. (1985). The satisfaction with life scale. Journal of Personality Assessment, 49(1), 71-75.

Diener, E., \& Lucas, R.E. (2000). Explaining differences in societal levels of happiness: Relative standards, need fulfillment, culture, and evaluation theory. Journal of Happiness Studies, 1(1), 41-78.

Fava, G.A., \& Sonino, N. (2008). The biopsychosocial model thirty years later. Psychotherapy and Psychosomatics, 77(1), 1-2.

Fraley, R.C., Heffernan, M.E., Vicary, A.M., \& Brumbaugh, C.C. (2011). The experiences in close relationships - Relationship Structures Questionnaire: A method for assessing attachment orientations across relationships. Psychological Assessment, 23(3), 615-625.

Fredrickson, B.L. (2001). The role of positive emotions in positive psychology: The broadenand-build theory of positive emotions. American Psychologist, 56(3), 218-226.

Gagné, M. (2003). The role of autonomy support and autonomy orientation in prosocial behavior engagement. Motivation and Emotion, 27(3), 199-223.

Haglund, M., \& Massaro, T.J. (2016). Ett positivt perspektiv på ungdomsutveckling: Betydelsen av socialt stöd och välbefinnande för gymnasieelevers skolinsatser. Szakdolgozat. Letöltve: 2018.05.14-én: http://www.diva-portal.org/smash/get/diva2:946186/FULLTEXT01. pdf 
Hills, P., \& Argyle, M. (2002). The Oxford Happiness Questionnaire: A compact scale for the measurement of psychological well-being. Personality and Individual Differences, 33, 1073-1082.

Hu, L.T., \& Bentler, P.M. (1998). Fit indices in covariance structure modeling: Sensitivity to underparameterized model misspecification. Psychological Methods, 3(4), 424-453.

Jantek, Gy., \& Vargha, A. (2016). A felnőtt kötődés korszerú mérési lehetősége: A közvetlen kapcsolatok élményei - kapcsolati struktúrák (ECR-RS) kötődési kérdőív magyar adaptációja párkapcsolatban élő felnőtt személyeknél. Magyar Pszichológiai Szemle, 71(3), 447-470.

Kern, M.L., Benson, L., Steinberg, E.A., \& Steinberg, L. (2016). The EPOCH measure of adolescent well-being. Psychological Assessment, 28(5), 586-597.

László, J. (2011). A tudományos narratív pszichológiai tartalomelemzés és a pszichológiai tartalomelemzés hagyományai. Pszichológia, 31(1), 3-15.

Lerner, J.V., Phelps, E., Forman, Y., \& Bowers, E.P. (2009). Positive youth development. In R. M. Lerner \& L. Steinberg (Eds.) Handbook of adolescent psychology: Individual bases of adolescent development ( ${ }^{\text {rd }}$ ed., vol. 1, 524-585). Hoboken, NJ: John Wiley \& Sons.

Lyubomirsky, S., King, L., \& Diener, E. (2005). The benefits of frequent positive affect: Does happiness lead to success? Psychological Bulletin, 131(6), 803-855.

Mansfield, E.R., \& Helms, B.P. (1982). Detecting multicollinearity. The American Statistician, 36(3a), 158-160.

Martos T., Sallay V., Désfalvi J., Szabó T., \& Ittzés A. (2014). Az Élettel való Elégedettség Skála magyar változatának (SWLS-H) pszichometriai jellemzői. Mentálhigiéné és Pszichoszomatika, 15(3), 289-303.

Moore, G.F., Cox, R., Evans, R.E., Hallingberg, B., Hawkins, J., Littlecott, H.J., et al. (2018). School, peer and family relationships and adolescent substance use, subjective wellbeing and mental health symptoms in Wales: a cross sectional study. Child Indicators Research, 11(6), 1951-1965.

Oláh, A. (1999). A tökéletes élmény megteremtését serkentő személyiségtényezók serdülőkorban. Iskolakultúra, 9(6-7), 15-27.

Oláh, A., \& Kapitány-Fövény, M. (2012). A pozitív pszichológia tíz éve. Magyar Pszichológiai Szemle, 67(1), 19-45.

Perczel-Forintos, D., Sallai, J., \& Rózsa, S. (2001). A Beck-féle Reménytelenség Skála pszichometriai vizsgálata. Psychiatria Hungarica, 16(6), 632-643.

Raja, S.N., McGee, R., \& Stanton, W.R. (1992). Perceived attachments to parents and peers and psychological well-being in adolescence. Journal of Youth and Adolescence, 21(4), 471-485.

Roisman, G.I., Masten, A.S., Coatsworth, J.D., \& Tellegen, A. (2004). Salient and emerging developmental tasks in the transition to adulthood. Child Development, 75(1), 123-133.

Rueger, S.Y., Malecki, C.K., \& Demaray, M.K. (2008). Gender differences in the relationship between perceived social support and student adjustment during early adolescence. School Psychology Quarterly, 23(4), 496.

Šeboková, G. (2018). Duálny model duševného zdravia a sociálna opora u žiakov stredných škôl. Školský psychológ/Školní psycholog, 19(1), 2-13.

Seligman, M. (2011). Flourish: A visionary new understanding of happiness and well-being. New York, NY: Free Press

Seligman, M. (2018). PERMA and the building blocks of well-being. The Journal of Positive Psychology, 13(4), 333-335.

Snyder, C.R. (2000). Hypothesis: There is hope. In C.R. Snyder (Ed.), Handbook of hope (3-21). New York, NY: Academic Press

Susánszky, É., Konkolÿ Thege, B., Stauder, A., \& Kopp, M. (2006). A WHO Jól-lét Kérdőív rövidített (WBI-5) magyar változatának validálása a Hungarostudy 2002 országos lakossági egészségfelmérés alapján. Mentálhigiéné és Pszichoszomatika, 7(3), 247-255. 
Szondy, M., \& Martos, T. (2014). A boldogság három arca: a Boldogság Orientáció Skála magyar változatának validálása. Mentálhigiéné és Pszichoszomatika, 15(3), 229-243.

Thomas, J.J., \& Daubman, K.A. (2001). The relationship between friendship quality and self-esteem in adolescent girls and boys. Sex Roles, 45(1-2), 53-65.

WHO (1948). Preamble to the Constitution of the World Health Organization as adopted by the International Health Conference, New York, 19-22 June, 1946; signed on 22 July 1946 by the representatives of 61 States (Official Records of the World Health Organization, no. 2, p. 100) and entered into force on 7 April 1948. Letöltve: 2018. 02. 28-án: http:/ / www. who. int/governance/eb/who_constitution_en.pdf

\section{Köszönetnyilvánítás}

A kutatást az Emberi Erőforrások Minisztériumának Felsőoktatási Intézményi Kiválósági Programja finanszírozta, a Pécsi Tudományegyetem 4. tématerületi „A hazai vállalatok szerepének növelése a nemzet újraiparosításában” programja keretében (szerződés száma: 20765-3/2018/FEKUTSTRAT).

\section{Nyilatkozat érdekütközésről}

A szerző ezúton kijelenti, hogy esetében nem állnak fenn érdekütközések. 


\section{Függelék: \\ Az EPOCH kérdőív magyar változata (EPOCH-H)}

Ez a kérdőív Rólad szól! Kérjük, olvasd el az alábbi állításokat! Húzd át vagy karikázd be azt az EGY számot az állítás mellett lévők közül, amelyik legjobban illik Rád. Légy őszinte - nincsenek helyes vagy helytelen válaszok!

1 = Szinte sohasem igaz; 2 = Ritkán igaz; 3 = Néha igaz; 4 = Általában igaz; $5=$ Szinte mindig igaz

\begin{tabular}{|l|c|c|c|c|c|}
\hline & $\begin{array}{c}\text { Szinte } \\
\text { sohasem } \\
\text { igaz }\end{array}$ & $\begin{array}{c}\text { Ritkán } \\
\text { igaz }\end{array}$ & $\begin{array}{c}\text { Néha } \\
\text { igaz }\end{array}$ & $\begin{array}{c}\text { Álta- } \\
\text { lában } \\
\text { igaz }\end{array}$ & $\begin{array}{c}\text { Szinte } \\
\text { mindig } \\
\text { igaz }\end{array}$ \\
\hline $\begin{array}{l}\text { 1. Ha valami jó dolog történik velem, } \\
\text { vannak olyan emberek, akikkel } \\
\text { szívesen megosztom a jó hírt. }\end{array}$ & 1 & 2 & 3 & 4 & 5 \\
\hline $\begin{array}{l}\text { 2. Ha valamibe belekezdek, be is } \\
\text { fejezem. }\end{array}$ & 1 & 2 & 3 & 4 & 5 \\
\hline $\begin{array}{l}\text { 3. Optimista vagyok a jövőmmel } \\
\text { kapcsolatban. }\end{array}$ & 1 & 2 & 3 & 4 & 5 \\
\hline $\begin{array}{l}\text { 4. Boldognak érzem magam. } \\
\text { 5. Ha valamit csinálok, annyira } \\
\text { élvezem, hogy nem is veszem észre, } \\
\text { mennyi idó telt el. }\end{array}$ & 1 & 2 & 3 & 4 & 5 \\
\hline $\begin{array}{l}\text { 6. Sok vidámságban van részem. } \\
\text { 7. Teljesen elmerülök abban, mit } \\
\text { csinálok. }\end{array}$ & 1 & 2 & 3 & 4 & 5 \\
\hline 8. Szeretem az életet. & 1 & 2 & 3 & 4 & 5 \\
\hline $\begin{array}{l}\text { 9. Addig dolgozom az iskolai } \\
\text { feladataimon, amíg el nem készülök } \\
\text { azokkal. }\end{array}$ & 1 & 2 & 3 & 4 & 5 \\
\hline $\begin{array}{l}\text { 10. Ha valamilyen problémám van, } \\
\text { mindig áll mellettem valaki. }\end{array}$ & 1 & 2 & 3 & 4 & 5 \\
\hline $\begin{array}{l}\text { 11. Annyira belemerülök abba, amit } \\
\text { csinálok, hogy minden másról } \\
\text { megfeledkezem. }\end{array}$ & 1 & 2 & 3 & 4 & 5 \\
\hline $\begin{array}{l}\text { 12. Amikor valami új dolgot tanulok, } \\
\text { elfeledkezem arról, mennyi idő is } \\
\text { telik el közben. }\end{array}$ & 1 & 2 & 3 & 4 & 5 \\
\hline
\end{tabular}




\begin{tabular}{|l|c|c|c|c|c|}
\hline & $\begin{array}{c}\text { Szinte } \\
\text { sohasem } \\
\text { igaz }\end{array}$ & $\begin{array}{c}\text { Ritkán } \\
\text { igaz }\end{array}$ & $\begin{array}{c}\text { Néha } \\
\text { igaz }\end{array}$ & $\begin{array}{c}\text { Álta- } \\
\text { lában } \\
\text { igaz }\end{array}$ & $\begin{array}{c}\text { Szinte } \\
\text { mindig } \\
\text { igaz }\end{array}$ \\
\hline $\begin{array}{l}\text { 13. Bizonytalan idókben a legjobbat } \\
\text { remélem. }\end{array}$ & 1 & 2 & 3 & 4 & 5 \\
\hline $\begin{array}{l}\text { 14. Vannak olyan emberek az } \\
\text { életemben, akik tényleg törődnek } \\
\text { velem. }\end{array}$ & 1 & 2 & 3 & 4 & 5 \\
\hline $\begin{array}{l}\text { 15. Úgy gondolom, hogy jó dolgok } \\
\text { fognak történni velem. }\end{array}$ & 1 & 2 & 3 & 4 & 5 \\
\hline $\begin{array}{l}\text { 16. Vannak olyan barátaim, akik } \\
\text { igazán fontosak nekem. }\end{array}$ & 1 & 2 & 3 & 4 & 5 \\
\hline $\begin{array}{l}\text { 17. Ha tervet készítek arra, hogy } \\
\text { hogyan csináljak valamit, akkor } \\
\text { ragaszkodom is hozzá. }\end{array}$ & 1 & 2 & 3 & 4 & 5 \\
\hline $\begin{array}{l}\text { 18. Hiszek abban, hogy a dolgok } \\
\text { megoldódnak, bármennyire } \\
\text { bonyolultnak is látsszanak. }\end{array}$ & 1 & 2 & 3 & 4 & 5 \\
\hline 19. Keményen dolgozom. & 1 & 2 & 3 & 4 & 5 \\
\hline 20. Vidám ember vagyok. & 1 & 3 & 4 & 5 \\
\hline
\end{tabular}

\section{Kiértékelés:}

Elmélyülés: 5., 7., 11. és 12. állítások átlaga

Kitartás: 2., 9., 17. és 19. állítások átlaga

Optimizmus: 3., 13., 15. és 18. állítások átlaga

Kapcsolódás: 1., 10., 14. és 16. állítások átlaga

Boldogság: 4., 6., 8. és 20. állítások átlaga

Összpontszám: mind a 20 állítás átlaga 


\title{
A multidimensional measure of adolescent psychological well-being: Psychometric properties of the Hungarian version of the EPOCH scale (EPOCH-H)
}

\author{
LÁNG, ANDRÁS
}

\begin{abstract}
Background: Psychological well-being is one of the most important research fields in positive psychology. In the last decade, measures of well-being are developed following the development of theoretical models in the field. However, it is developmentally inappropriate to expect the dimensions of well-being to be fully fledged in adolescence. The EPOCH measure by Kern, Benson, Steinberg, and Steinberg (2016) is a good response for this challenge. Aim: The aim of this research was the Hungarian adaptation of EPOCH. Structural reliability, concurrent, discriminant, and incremental validity of the Hungarian translation were tested. Method: Seven hundred and fifty-eight secondary school students between the ages of 14 to 19 participated in the study. After receiving informed consent from their parents, the adolescents completed the Hungarian translation of EPOCH and measures of general well-being, satisfaction with life, need satisfaction, and general attachment. Results: Confirmatory factor analysis indicated a good fit between the original five-dimensional model and our data. Correlations with other measures were of medium strength in average, which indicated an adequate concurrent and discriminative validity of EPOCH-H. Dimensions of EPOCH-H were significantly correlated with general attachment and need satisfaction even after controlling for the effects of traditional indices of well-being. Conclusions: EPOCH-H is an age-appropriate and theoretically sound measure of well-being that can be used by any researcher who wants to measure multiple dimensions of well-being in adolescents via self-report.
\end{abstract}

Keywords: adolescence, well-being, PERMA, EPOCH, psychometrics

\footnotetext{
A cikk a Creative Commons Attribution 4.0 International License (https:/ / creativecommons.org/ licenses/by/4.0/) feltételei szerint publikált Open Access közlemény, amelynek szellemében a cikk bármilyen médiumban szabadon felhasználható, megosztható és újraközölhető, feltéve, hogy az eredeti szerző és a közlés helye, illetve a CC License linkje és az esetlegesen végrehajtott módosítások feltüntetésre kerülnek. (SID_1)
} 